\title{
Studies on Earnings Management and Financial Statement Fraud in Corporate Firms
}

\author{
Noorul Azwin binti Md Nasir ${ }^{1}$, Muhammad Jahangir Ali $^{2} \&$ Noorshella binti Che Nawi ${ }^{1}$ \\ ${ }^{1}$ Faculty of Entrepreneurship and Business, Universiti Malaysia Kelantan, Malaysia \\ 2 School of Accountancy, La Trobe University, Melbourne, Australia \\ Correspondence: Noorul Azwin binti Md Nasir, Faculty of Entrepreneurship and Business, Universiti Malaysia \\ Kelantan, Malaysia.
}

Received: May 1, 2019

Accepted: June 1, 2019

Online Published: July 7, 2019

doi:10.5430/rwe.v10n2p15

URL: https://doi.org/10.5430/rwe.v10n2p15

\begin{abstract}
The purpose of this paper is to explain the transformation of earnings management into financial statement fraud. Related papers on earnings management and financial statement fraud were intensively reviewed. Although there are some overlaps in both concepts, application of earnings management is not always related to financial statement fraud. Earnings management can occur for a number of reasons, including unintentional errors and legitimate disagreement over GAAP. Results of this study indicate that accounting records are allowed to be managed up to certain hedge. Crossing the hedge would lead the organization to be convicted in illegal financial reporting.
\end{abstract}

Keywords: earnings management, financial statement, financial statement fraud

\section{Empirical Studies on Earnings Management and Financial Statement Fraud}

It is posited that failed firms are involved in earnings management up to four years prior to a firm's failure (García Lara, Osma, \& Neophytou, 2009). Dechow, Sloan, and Sweeney (1996) write that financial statement fraud firms have higher abnormal accruals in the first three years prior to fraud conviction. This indicates that firms are involved in manipulating their income to present false financial statement reports. Other studies on earnings management have focused on accruals (Beneish, 1999; Callen, Robb, \& Segal, 2008; Guidry, J Leone, \& Rock, 1999; K. L. Jones, Krishnan, \& Melendrez, 2008; Kasznik, 1999; McNichols \& Wilson, 1988; Rosner, 2003). It is only recently that real earnings management activities have been acknowledged as a new field of research.

\subsection{Accruals and Real Earnings Management}

Healy and Wahlen (1999) draw attention to popular wisdom that earnings management does exist, but is rarely confirmed. Reported earnings in financial statement are subjected to accruals and real earnings management (Enomoto, Kimura, \& Yamaguchi, 2015; Francis, Hasan, \& Li, 2016; Xu, Taylor, \& Dugan, 2007; Hye \& Lau 2015). A number of widely discussed models to detect abnormal accruals in earnings management are explained in empirical studies in the 1980s and 1990s (see Beneish, 1999; DeAngelo, 1981; Dechow, Sloan, \& Sweeney, 1995; Healy, 1985; J. J. Jones, 1991). McNichols and Wilson (1988) investigate whether firms with higher bad debt provisions manipulate their accrual-based earnings. Using abnormal accruals as a proxy to earnings management, the study indicates that managers implement income decreasing accruals when firms' income is extremely low. DeFond and Jiambalvo (1994) analyse abnormal accruals of firms that violate the debt covenant. They find substantial evidence that earnings are modified one year before the violation. Beneish (1999) uses sample of 2406 firms that manipulate earnings from 1982 to 1992. The author develops a model for detecting earnings management and discovers that approximately half of the sampled firms are involved in earnings management prior to public discoveries. Later, Guidry et al. (1999) prove managers use abnormal accruals to maximise personal short-term bonuses due to the advantage of information asymmetry with upper level executives. Kasznik (1999) finds evidence that managers increase their earnings after over-estimating their forecast incomes. Callen et al. (2008) investigate the probability of firms' manipulating revenues using 1990 to 1994 restatement data concerning 1954 firms. The study emphasises that firms are more likely to manipulate revenue from GAAP if firms are in deficit or forecasting losses. Another study by Rosner (2003) investigates the manipulation of earnings in failing firms. Here, failing firms are defined as businesses that are previously engaged in financial statement fraud to conceal the distress condition. A total of 586 sample firms which are identified as bankrupt from 
1985 to 1998 are used. The author proves the hypothesis that failing firms are more likely to manipulate their accruals by engaging in income increasing earnings manipulation.

Reported earnings in financial statement are subjected to accruals and real earnings management (Enomoto et al., 2015; Francis et al., 2016; Xu et al., 2007; Zhu \& Chen 2018). However, the literature on earnings management through real earnings management is fairly recent. The pioneer study for real earnings management is conducted by Roychowdhury (2006). Roychowdhury (2006) defines real earnings management as "management actions that deviate from normal business practices, undertaken with the primary objectives of meeting certain earnings threshold" (p.336). Empirical studies explain that firms manage earnings using real activities. In real earnings management activities, alteration is made on cash flow from operations, production costs and discretionary expenses (Roychowdhury, 2006). A total of 17,338 firm years' data from 1987 and 2001 are collected to investigate earnings management through real earnings management activities. The excessive price discounts and overproduction are measured by abnormally low cash flow from operations and abnormally high production costs, respectively. The author discovers that firms manage their earnings through price discounting, lenient credit terms and overproduction to meet analysts' forecasts. A study of real earnings management is important because changes made in real transactions may be costly (Ewert \& Wagenhofer, 2005) and may cause firms to collapse (Yu, 2008). Graham, Harvey, and Rajgopal (2005) posit that managing earnings by adjusting current income may reduce firm value in the long term. Furthermore, the alteration may lead to poor subsequent performance (Gunny, 2005; Roychowdhury, 2006; Wonyra, 2018). In addition, real earnings management may simultaneously reduce business performance and impose higher financial obligations (Demski, 2004). For instance, if real earnings manipulation succeeds and firms are able to meet their expected earnings, then they are obliged to deliver financial rewards to their managers (Yu, 2008; Xu \& Zhang 2018). Furthermore, the time and effort spent by executives to manipulate real earnings activities are better focused on improving other valuable issues that may increase their firms' value. Real earnings management activities also have real economic costs (Bar-Gill \& Bebchuk, 2002). For example, in managing cash flow, firm offers customers sales discounts and lenient credit terms. In the long run, the customers may expect the same offers from the firms. Therefore, it is possible that cash flows in future periods are affected negatively by the actions taken in the current year to increase earnings. A study conducted by Enomoto et al. (2015) finds that real earnings management increases in a country with stronger investor protection.

\section{Revolution of Earnings Management and Financial Statement Fraud}

Recent years have witnessed changes in financial reporting formats. While the are exchange rules in place, the occurrence of financial statement fraud is still disturbing. Chen, Cheng, and Wang (2015) provide evidence that the effectiveness of organization structure is important in reducing earnings management, hence minimizing financial statement fraud risks. This include accounting professionals to rationalize earnings management decision and incorporate corporate ethics and social responsibility in performing their duties (Shafer, 2015). Subsequently, weak controls will give managers the opportunity to commit fraud as earnings management is outweigh (Donelson, Ege, \& McInnis, 2016; Zhang \& Gao 2018).

Ronen and Yaari (2007) classify earnings management as white (beneficial), gray (manipulation within boundaries) and black (misrepresentation and fraud). The authors add that when earnings are managed for personal benefit, this means the management takes advantage of the flexibility in the accounting choices for signalling accurate information of firms' overall performance. In contrast, when earnings is manipulated within boundaries, (i.e., GAAP), it is about choosing the accounting treatment that maximises the utility of management and be economically efficient. Lastly, the black classification of earnings management is the evident intention to misrepresent a firm's financial reports. It is argued that not all earnings management are misleading (Chung, Firth, \& Kim, 2002). However, Akers, Giacomino, and Bellovary (2007) propose that financial statement fraud is an indication of earnings management. Similarly, Soltani (2009) contends that financial statement fraud often starts with earnings management. Bukit and Iskandar (2009) explain that earnings manipulation ranges from financial statement fraud to earnings management. 


\begin{tabular}{|c|c|c|}
\hline & \multirow[t]{2}{*}{ Accounting Choices } & \multirow[t]{2}{*}{ "Real" Cash Flow Choices } \\
\hline & & \\
\hline & $\begin{array}{l}\text { Overly aggressive recognition of } \\
\text { provisions or reserves }\end{array}$ & Delaying sales \\
\hline \multirow[t]{2}{*}{$\begin{array}{l}\text { "Conservative } \\
\text { Accounting" }\end{array}$} & $\begin{array}{l}\text { Overvaluation of acquired in-process } \\
\text { R\&D in purchase acquisitions }\end{array}$ & $\begin{array}{l}\text { Accelerating } R \& D \text { or } \\
\text { advertising expenditures }\end{array}$ \\
\hline & $\begin{array}{l}\text { Overstatement of restructuring } \\
\text { charges and asset write-offs }\end{array}$ & \\
\hline $\begin{array}{l}\text { "Neutral } \\
\text { Earnings" }\end{array}$ & $\begin{array}{l}\text { Earnings that result from a neutral } \\
\text { operation of the process }\end{array}$ & \\
\hline \multirow{4}{*}{$\begin{array}{l}\text { "Aggressive } \\
\text { Accounting" }\end{array}$} & $\begin{array}{l}\text { Understatement of the provision for } \\
\text { bad debts }\end{array}$ & $\begin{array}{l}\text { Postponing R\&D or advertising } \\
\text { expenditures }\end{array}$ \\
\hline & $\begin{array}{l}\text { Drawing down provisions or reserves } \\
\text { in an overly aggressive manner }\end{array}$ & Accelerating sales \\
\hline & Violates GAAP & \\
\hline & Recording sales before it is realizable & \\
\hline \multirow{3}{*}{$\begin{array}{l}\text { "Fraudulent } \\
\text { Accounting" }\end{array}$} & Recording fictitious sales & \\
\hline & Backdating sales invoices & \\
\hline & $\begin{array}{l}\text { Overstating inventory by recording } \\
\text { fictitious inventory }\end{array}$ & \\
\hline
\end{tabular}

Figure 1. Distinctions between fraud and earnings management

Adopted from Dechow and Skinner (2000)

Dechow and Skinner (2000) illustrate the difference between financial statement fraud and earnings management (refer to Figure 1). Figure 1 shows that earnings management can constitute a form of financial reporting abuse. However, there are accounting standards established to control earnings management. Not all material misstatements or omissions are a result of financial statement fraud. They can be an unintentional error or misinterpretation of standards and regulations. The ambiguousness of accounting practices has extended the preliminary intention of earnings management into financial statement fraud (Ronen \& Yaari, 2007; Zheng, 2018).

\section{Conclusion}

For this study, it is important to note that financial statement fraud and earnings management are not the same. Although there are some overlaps in both concepts, application of earnings management is not always related to financial statement fraud. Earnings management can occur for a number of reasons, including unintentional errors and legitimate disagreement over GAAP. In other words, it is accepted for financial numbers to be changed and altered within limits. However, if the financial reports are altered across the restricted limits, financial statement fraud takes place. With financial statement fraud, it is certain that the actor has the intention and desire to hide manipulations and actual financial performance from financial statement users.

\section{References}

Akers, M., Giacomino, D., \& Bellovary, L. (2007). Earnings management and its implications: Educating the accounting profession. The CPA Journal. August, 77(8), 64-68.

Bar-Gill, O., \& Bebchuk, L. (2002). Misreporting corporate performance. Paper presented at the Harvard Law and Economics Discussion Paper. https://doi.org/10.2139/ssrn.354141 
Beneish, M. D. (1999). The detection of earnings manipulation. Financial Analysts Journal, 55(5), 24-36. https://doi.org/10.2469/faj.v55.n5.2296

Bukit, R. B., \& Iskandar, T. M. (2009). Surplus Free Cash Flow, Earnings Management and Audit Committee. International Journal of Economics and Management, 3(1), 204-223.

Callen, J. L., Robb, S. W., \& Segal, D. (2008). Revenue manipulation and restatements by loss firms. Auditing: A Journal of Practice \& Theory, 27(2), 1-29. https://doi.org/10.2308/aud.2008.27.2.1

Chen, X., Cheng, Q., \& Wang, X. (2015). Does increased board independence reduce earnings management? Evidence from recent regulatory reforms. Review of Accounting Studies, 20(2), 899-933. https://doi.org/10.1007/s11142-015-9316-0

Chung, R., Firth, M., \& Kim, J.-B. (2002). Institutional monitoring and opportunistic earnings management. Journal of Corporate Finance, 8(1), 29-48. https://doi.org/10.1016/S0929-1199(01)00039-6

DeAngelo, L. (1981). Auditor size and audit quality. Journal of Accounting and Economics, 3(3), 183-199. https://doi.org/10.1016/0165-4101(81)90002-1

Dechow, P. M., \& Skinner, D. J. (2000). Earnings management: Reconciling the views of accounting academics, practitioners, and regulators. Accounting Horizons, 14(2), 235-250. https://doi.org/10.2308/acch.2000.14.2.235

Dechow, P. M., Sloan, R. G., \& Sweeney, A. P. (1995). Detecting earnings management. Accounting Review, 70(2), 193-225.

Dechow, P. M., Sloan, R. G., \& Sweeney, A. P. (1996). Causes and consequences of earnings manipulation: An analysis of firms subject to enforcement actions by the SEC. Contemporary Accounting Research, 13(1), 1-36. https://doi.org/10.1111/j.1911-3846.1996.tb00489.x

DeFond, M. L., \& Jiambalvo, J. (1994). Debt covenant violation and manipulation of accruals. Journal of Accounting and Economics, 17(1), 145-176. https://doi.org/10.1016/0165-4101(94)90008-6

Demski, J. S. (2004). Endogenous expectations. The Accounting Review, 79(2), 519-539. https://doi.org/10.2308/accr.2004.79.2.519

Donelson, D. C., Ege, M., \& McInnis, J. (2016). Internal control weaknesses and financial reporting fraud. Auditing: A Journal of Practice and Theory. https://doi.org/10.2308/ajpt-51608

Enomoto, M., Kimura, F., \& Yamaguchi, T. (2015). Accrual-based and real earnings management: An international comparison for investor protection. Journal of Contemporary Accounting \& Economics, 11(3), 183-198. https://doi.org/10.1016/j.jcae.2015.07.001

Ewert, R., \& Wagenhofer, A. (2005). Economic effects of tightening accounting standards to restrict earnings management. The Accounting Review, 80(4), 1101-1124. https://doi.org/10.2308/accr.2005.80.4.1101

Francis, B., Hasan, I., \& Li, L. (2016). Abnormal real operations, real earnings management, and subsequent crashes in stock prices. Review of Quantitative Finance and Accounting, 46(2), 217-260. https://doi.org/10.1007/s11156-014-0468-y

García Lara, J. M., Osma, B. G., \& Neophytou, E. (2009). Earnings quality in ex-post failed firms. Accounting and Business Research, 39(2), 119-138. https://doi.org/10.1080/00014788.2009.9663353

Graham, J. R., Harvey, C. R., \& Rajgopal, S. (2005). The economic implications of corporate financial reporting. Journal of Accounting and Economics, 40(1), 3-73. https://doi.org/10.1016/j.jacceco.2005.01.002

Guidry, F., Leone, A. J., \& Rock, S. (1999). Earnings-based bonus plans and earnings management by business-unit managers. Journal of Accounting and Economics, 26(1), 113-142. https://doi.org/10.1016/S0165-4101(98)00037-8

Gunny, K. A. (2005). What are the consequences of real earnings management?

Healy, P. M. (1985). The effect of bonus schemes on accounting decisions. Journal of Accounting and Economics, 7(1), 85-107. https://doi.org/10.1016/0165-4101(85)90029-1

Healy, P. M., \& Wahlen, J. M. (1999). A review of the earnings management literature and its implications for standard setting. Accounting Horizons, 13(4), 365-383. https://doi.org/10.2308/acch.1999.13.4.365

Hye, Q. M. A., \& Lau, W. Y. (2015). Trade openness and economic growth: empirical evidence from India. Journal of Business Economics and Management, 16(1), 188-205. https://doi.org/10.3846/16111699.2012.720587 
Jones, J. J. (1991). Earnings management during import relief investigations. Journal of Accounting Research, 29(2), 193-228. https://doi.org/10.2307/2491047

Jones, K. L., Krishnan, G. V., \& Melendrez, K. D. (2008). Do Models of Discretionary Accruals Detect Actual Cases of Fraudulent and Restated Earnings? An Empirical Analysis*. Contemporary Accounting Research, 25(2), 499-531. https://doi.org/10.1506/car.25.2.8

Kasznik, R. (1999). On the association between voluntary disclosure and earnings management. Journal of Accounting Research, 29(2), 193-228. https://doi.org/10.2307/2491396

McNichols, M., \& Wilson, G. P. (1988). Evidence of earnings management from the provision for bad debts. Journal of Accounting Research, 26, 1-31. https://doi.org/10.2307/2491176

Ronen, J., \& Yaari, V. (2007). Earnings management: Emerging insights in theory, practice, and research (Vol. 3). New York: Springer Verlag.

Rosner, R. L. (2003). Earnings manipulation in failing firms. Contemporary Accounting Research, 20(2), 361-408. https://doi.org/10.1506/8EVN-9KRB-3AE4-EE81

Roychowdhury, S. (2006). Earnings management through real activities manipulation. Journal of Accounting and Economics, 42(3), 335-370. https://doi.org/10.1016/j.jacceco.2006.01.002

Shafer, W. E. (2015). Ethical climate, social responsibility, and earnings management. Journal of Business Ethics, 126(1), 43-60. https://doi.org/10.1007/s10551-013-1989-3

Soltani, B. (2009). A closer look at financial reporting. The Internal Auditor, 66(5), 39-43.

Wonyra, K. O. (2018). Industrialization and Economic Growth in Sub-Saharan Africa: The Role of Human Capital in Structural Transformation. Journal of Empirical Studies, 5(1), 45-54. https://doi.org/10.18488/journal.66.2018.51.45.54

Xu, Z., Taylor, G., \& Dugan, M. (2007). Review of real earnings management literature. Journal of Accounting Literature, 26, 195-228.

Xu, Q., \& Zhang, H. (2018). Optimal Bid Strategies in Crowdsourcing Contest Based on Multi-Attribute Auctions. International Journal of Emerging Trends in Social Sciences, 4(2), 67-74. https://doi.org/10.20448/2001.42.67.74

$\mathrm{Yu}, \mathrm{W}$. (2008). Accounting-based earnings management and real activities manipulation. Georgia Institute of Technology.

Zhang, K., \& Gao, J. (2018). Coordination Strategy of Dual-Channel Supply Chain for Fresh Product Under the Fresh-Keeping Efforts. International Journal of Emerging Trends in Social Sciences, 4(2), 75-85. https://doi.org/10.20448/2001.42.75.85

Zheng, J. (2018). The Incorporation of Subject Knowledge in Teaching Scientific Translation. International Journal of English Language and Literature Studies, 7(2), 45-49. https://doi.org/10.18488/journal.23.2018.72.45.49

Zhu, C., \& Chen, L. (2018). An Analysis of the Development of China's Commercial Banks under the Structural Reform of the Supply Side. Journal of Accounting, Business and Finance Research, 4(1), 1-8. https://doi.org/10.20448/2002.41.1.8 